\title{
Evidence-based gender equality policy and pay in Latin America and the Caribbean: progress and challenges
}

\author{
Rosangela Bando* (i)
}

\author{
*Correspondence: \\ rosangelab@iadb.org \\ Office of Strategic Planning \\ and Development \\ Effectiveness, Inter-American \\ Development Bank, 1300 \\ New York Avenue, N.W., \\ Washington, DC 20577, USA
}

\begin{abstract}
This paper aims to identify the main contributing factors to the observed gender pay inequality in the last 10 years in Latin America and the Caribbean. It also aims to identify the main restrictions to design evidence-based policy. The average woman in the region works $25 \mathrm{~h}$ more per month than the average man. Yet only half of women in the region are paid for or otherwise profit from their work. Work without formal pay leads to weak protection of human rights and limits civic participation. Moreover, gender inequality deters economic development and fosters income inequality. Research shows gender gaps result from the interactions of social norms and biological differences. The challenges to generating effective policies include the difficulty of identifying relevant mechanisms to explain gaps, the cost of collecting and analyzing relevant data, and the complexity associated with determining pertinent features of gender gaps. Collection and analysis of those mechanisms, data, and features are critical to learning how to correct gender gaps going forward.
\end{abstract}

Keywords: Gender inequality, Gender gaps, Latin America and the Caribbean

JEL Classification: J10, J16, J70, O54

\section{Introduction}

Men and women may sometimes have different roles, which impact the exercise of human rights. For example, in Latin America and the Caribbean region women work more yet get less formal compensation or benefits in exchange for it. The average woman in the region works $25 \mathrm{~h}$ more per month than the average man (United Nations 2015b), and half the women in the region work for no pay or profit at all (World Bank 2016). A pay gender gap implies limits to individual choice based on sex, thus violating individual human rights. Note that the word "gender" refers to a social construct. Gender denotes a group of behaviors that society considers appropriate for men and women (WHO 2015). Thus, gender gaps refer to differentials between the sexes derived from different treatment by society. The word "sex," on the other hand, denotes the biological and physiological characteristics that separate men and women (WHO 2015). ${ }^{1}$

\footnotetext{
1 "Male" and "female" are sex categories. "Masculine" and "feminine" are gender categories.
} 
Governments in the region need policies to promote equal enjoyment by men and women of human rights, including the right to reap economic and social benefits. Despite the current gender gap in Latin America and the Caribbean, there has been significant progress in the region. Women have increased their labor participation since the 1990s more than in any other region in the world. The percentage of employed women 15 years of age and older increased from 38 to 50\% from 1991 to 2014 in Latin America and the Caribbean, in contrast to a decrease from 49 to $46 \%$ in the rest of the world (World Bank 2016). ${ }^{2}$ However, it is still an open question how much of this labor increase constitutes a substitution for unpaid work and how much of it is actual additional labor. Economists cannot fully explain why women continue to assume unpaid work in society and bear the cost associated with it. Neither is it clear why society continues to bear the social and economic costs associated with gender segregation into occupations.

Economists have studied labor and pay gender gaps since the 1950s. The general argument built to date includes several components. Biology and social norms interact to determine skills. Skills and technology produce goods and services that individuals trade. Institutions regulate trade to reduce transaction costs. Thus, biology, social norms, technology, and institutions influence the pay gender gap. Researchers have found that these factors interact and influence the gender gap at several stages. Therefore, researchers are challenged to find simple solutions. Policymakers and researchers are working together to address the challenge. This paper aims to aid these efforts. It summarizes the progress in research, explains the rationale for the main theories to explain gender gaps, summarizes pay gap studies in the region in the last 10 years, and lists the main challenges to generating evidence-based gender equality policy in Latin America and the Caribbean.

Studying gender gaps is important for two reasons. The first is that gender gaps limit individual choice based on sex. The second article in the Declaration of Human Rights states: "Everyone is entitled to all the rights and freedoms set forth in this Declaration, without distinction of any kind, such as [...] sex" (United Nations 1948). However, the observed inequality in pay between men and women is related to limits to freedoms. For instance, Duflo (2012) noted that gender would not influence spending if informal mechanisms enabled individuals to voice their preferences. However, women allocate more resources than men to the education and health of children (Thomas 1990; Duflo 2003; Duflo and Udry 2004). In Mexico, married women's earnings reduce within-household inequality because they share their income with other household members (CamposVázquez et al. 2012). In the government sphere, the gender of the decision-maker also influences public spending (Yañez-Pagans 2014). Thus, pay gaps reflect gaps in the ability of individuals to voice their preferences.

The second reason why it is important to study gender gaps is that these gaps deter economic growth. Indeed, women tend to invest more than men in human capital for future generations (Duflo 2003; Duflo and Udry 2004). Gender gaps also undermine collective action. Women are more likely to be out of the labor market or to work in the informal sector (ILO 2013b, 2015b). Thus, tax collection and social coverage is particularly limited for women. ${ }^{3}$ In addition, women are less likely to participate in the

\footnotetext{
${ }^{2}$ Employment is defined as work performed for others in exchange for pay or profit (ILO 2013a).

${ }^{3}$ For evidence on pensions, see Bosch et al. (2013).
} 
Table 1 The gender gap in paid work, employment, and earnings in developing countries and Latin America and the Caribbean. Source: Author's calculations based on data from United Nations (2015b) for columns (A), (B) and (C); World Bank (2016) for column (D); and ECLAC (2015) for column (E)

\begin{tabular}{|c|c|c|c|c|c|}
\hline & \multirow{2}{*}{\multicolumn{3}{|c|}{$\begin{array}{l}\text { Developing countries } \\
\text { Minutes worked per day, } 2010\end{array}$}} & \multicolumn{2}{|c|}{ Latin America and the Caribbean } \\
\hline & & & & \multirow{2}{*}{$\begin{array}{l}\text { Percent of the population } \\
\text { age } 15+\text { employed, } 2014\end{array}$} & \multirow{2}{*}{$\begin{array}{l}\text { Earnings of women } \\
\text { relative to men (ratio), } \\
2013\end{array}$} \\
\hline & Paid & Unpaid & Total & & \\
\hline & (A) & (B) & $(C)=(A)+(B)$ & (D) & (E) \\
\hline Men & 300 & 80 & 380 & 75 & 1 \\
\hline Women & 160 & 270 & 430 & 50 & 0.87 \\
\hline Gap & 140 & -190 & -50 & 25 & 0.13 \\
\hline
\end{tabular}

Employment is defined as work performed for others in exchange for pay or profit (ILO 2013a)

democratic process as leaders (Zetterberg 2009), and gender segregation into certain occupations also contributes to deterring economic development (World Bank 2012).

The relationship between women's empowerment and economic development is not trivial. Evidence shows that simply endowing women with resources does not always result in economic gains. For example, Udry (1996) found that men's farming plots were more productive than women's plots in Africa. Banerjee et al. (2015) found no evidence the gender of the recipient of microcredit loans in Mexico mattered for returns. Overcoming gender gaps can be difficult, and perpetuating gender gaps is likely to deter some paths to economic growth. ${ }^{4}$

This study focuses on the gender gap in pay and how it is related to other important gender issues in the region. There are three features of the scope and limitations of this study. First, the study focuses on economic labor models of individual choice. One concern related to gender issues is that social norms drive gender gaps. Therefore, other studies could consider studying gender gaps from a collective decision-making perspective. Second, this study discusses aggregate evidence that allows for establishing relationships among contributing factors. As a result, it leaves out a rich body of literature on case studies or descriptions of behavior based on small samples. Third, this study will discuss policies related to gender issues in the last 10 years. A historical view demands a broader discussion and is beyond the scope of this work.

\section{Gender gaps in pay}

This section describes the formal pay gap related to gender, highlighting three ways into which gender pay gaps can be split: the pay/no-pay choice, the occupational choice conditional on receiving pay, and the wage gap conditional on an occupation.

First, women disproportionately spend more time in non-remunerated activities. Columns (A) and (B) of Table 1 show the minutes worked per day by sex in developing countries. Women spent $1 \mathrm{~h}$ and $41 \mathrm{~min}$ on unpaid work for every hour of paid work in 2010 (United Nations 2015a). The equivalent for men was 13 min (United Nations 2015a). Overall, women work 50 more minutes per day than men both in paid and

\footnotetext{
${ }^{4}$ For an excellent discussion on the relationship between economic empowerment and economic development, see Duflo (2012)
} 
unpaid work. This difference adds up to $25 \mathrm{~h}$ or about one day of work per month for women. However, women are less likely to get paid than men for all of that work because they spend more time producing goods and services for household or family consumption. ${ }^{5}$ For example, women spent $14 \mathrm{~h}$ preparing food and $10 \mathrm{~h}$ cleaning the house per week in 2014 in Mexico (INEGI 2015). In contrast, men spent four hours preparing food and four hours cleaning the house per week (INEGI 2015).

The employment rate for persons ages 15 or older in Latin America and the Caribbean is informative as to the share of men and women working in paid or for-profit activities. The employment rate was $50 \%$ for women and $75 \%$ for men in 2014 (Table 1, column (D)) (World Bank 2016). ${ }^{6}$ Thus, women spend more time on household and family activities than men and are less likely to hold jobs for pay or profit.

Employment gaps between men and women are not new, and they used to be larger. Gender gaps in employment closed in Latin America and the Caribbean between 1991 and 2014. Figure 1 shows employment of men and women in the region and in the rest of the world. Employment among women decreased from 49 to $46 \%$ worldwide but increased from 38 to 50\% from 1991 to 2014 in Latin America and the Caribbean (World Bank 2016). Employment among men declined slightly from 78 to $75 \%$ in Latin America and the Caribbean, and from 76 to $72 \%$ in the rest of the world (World Bank 2016). At this average rate of change in employment among men and women, the gap between them would close by 2056 , reaching a global employment rate of $71 \%$.

The second way to look at gender pay gaps is by considering that people who work for pay segregate into occupations according to gender. Worldwide, women tend to work in jobs related to education, health, welfare, and the arts and humanities, while men segregate into agriculture, engineering, manufacturing, construction, science, and services (World Bank 2012). Segregation into occupations is related to pay. For example, using data from Bolivia, Chile, Ecuador, Honduras, Nicaragua, El Salvador, Uruguay, and Paraguay from 2007, Nopo (2012) found that women held only 33\% of top-paying jobs related to business, law, health, computer science, government, and science. The International Labour Organization (ILO) estimates that $60 \%$ of chief executive officers in Latin America and the Caribbean are men, while $74 \%$ of them are men are worldwide (ILO 2015a). Moreover, only 40\% of firms are owned by women in Latin America and the Caribbean, while 37\% of firms are owned by women worldwide (ILO 2015a). Thus, women may receive less money for their work because they do not work in the best paid occupations.

Even within specific occupations, women tend to get paid less than men, which constitutes the third way of looking at gender pay gaps. Nopo (2012) found the top 10 paying jobs in his study paid US $\$ 479$ to men per month but only US\$302 to women, an approximate $30 \%$ difference. Wage gaps persisted even when considering age,

\footnotetext{
${ }_{5}^{5}$ Productive activities that involve within-household transactions are difficult to value because the market often does not correctly price them. Moreover, measuring activities that produce goods and services for household consumption is conceptually difficult. For example, a person reading a book to his or her child may be doing so as a service to the household, for their own pleasure, or both. Persons working on own-use household or family production are not considered employed. Persons working on own-use consumption are considered out of the labor force and not part of the economically active population (the labor force). The services produced for own-use consumption are not included in the system of national accounts (ILO 2013a).

6 Worldwide, these figures were $46 \%$ for women and $72 \%$ for men.
} 

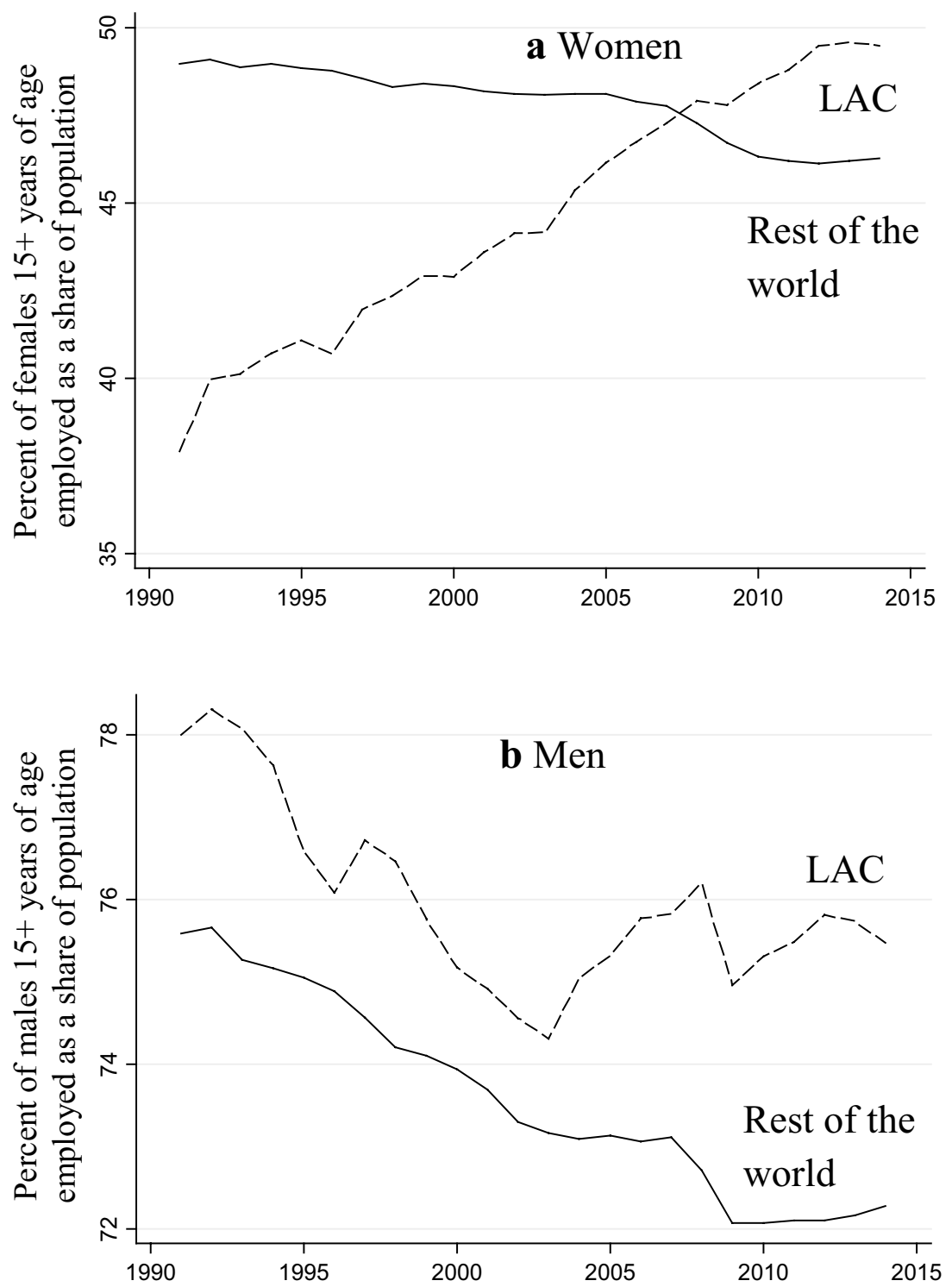

Fig. 1 Percentage of men and women employed, Latin America and the Caribbean versus the rest of the world, 1991-2014. Source: Author's calculations based on data from World Bank (2016). Percentages are computed as a share of the total population. For the countries, economies, and territories included in Latin America and the Caribbean and the rest of the world. LAC Latin America and the Caribbean

education, number of children, presence of another income earner at home, employment, and number of hours worked per week. Column (E) in Table 1 shows that women earned 87 cents for every $\$ 1$ that men earned in Latin America and the Caribbean in 2013. The relationship is not exclusively related to wage gaps. For example, Angelucci, Karlan, and Zinman (2015) found that microcredit for women to start a business did not always increase their income in Mexico. The evidence suggests that women tend to get less money for their work relative to men even when both groups are compared within a specific occupation.

In summary, men tend to work in paid occupations, while women tend to work in unpaid ones. When women work for pay, they tend to work in lower-paid occupations 
relative to men. Within a specific occupation, women are paid less than men, although these gaps have been closing over time.

\section{Causes of gender gaps in pay}

This section summarizes the main theories to explain gender gaps in pay. Since Ricardo (1821), economists have modeled gaps in individual skills and abilities to explain gaps in labor. In 1965, Becker proposed a model that became standard to analyze occupational choice (Becker 1965). In a basic model, individuals choose between paid and unpaid work by considering the trade-offs-or benefits and costs-associated with the returns derived from each activity. Benefits and costs depend on individual characteristics, social preferences, technology, and institutions.

\subsection{Individual characteristics}

Economists have specifically explored gender gaps related to education, experience, and preferences since the 1970s (Mincer and Polachek 1974). Both individual biological features and education influence individual skills and productivity. Gender norms influence education and occupational choice. These conclusions have been widely accepted since debate on the topic started (Becker 1971; World Bank 2012; United Nations 2015a).

\subsubsection{The role of nature}

Biological predisposition in individuals influences their productivity in certain positions. For example, certain positions in construction may demand lifting heavy objects. The average man can lift heavier objects than the average woman. Another biological difference between the sexes is that of pregnancy, which affects the physiology of women around the time of childbirth. Women experience hormonal changes after giving birth that trigger processes such as milk production. Such processes may induce a transitory change in preferences. For example, women become more sensitive and responsive to infant cry after childbirth (Marlin et al. 2015; Levine et al. 2007; De Pisapia et al. 2013; Noriuchi, Kikuchi, and Senoo 2008). By undergoing such changes, women may face a higher cost than men to forgo the care of infants during a sensitive period. Biology may also play a role in shaping non-transitory preferences. For example, exposure to testosterone before birth influences competition, dominance, and risk preferences in adults (Baron-Cohen 2003; Dreber and Hoffman 2007). Moreover, the menstrual cycle may influence risk preferences, altruism, trust, and reciprocity (Buser 2012; Pearson and Burkhard 2013). Indeed, laboratory experiments find differences across genders in these dimensions (for a review, see Bertrand 2011). Biological processes may induce differences in skills and transitory and non-transitory preferences.

\subsubsection{The role of nurture}

Education is an important way to acquire skills. ${ }^{7}$ As of 2010, 110 girls were completing secondary education in Latin America and the Caribbean for every 100 boys (UNESCO

\footnotetext{
${ }^{7}$ An important set of policies since the 1960s has focused on guaranteeing equal access to education. Indeed, member countries of the United Nations signed the Convention against Discrimination in Education in 1960 (UNESCO $2016 \mathrm{a}$ b). Six countries in Latin America and the Caribbean ratified the convention in the same decade. By 2015,19 countries had ratified it.
} 
2016a, b). Currently, women in Latin America and the Caribbean attain more years of education than men (World Bank 2016).

Despite achievements in years of education, differences in skills between the sexes remain. Consider the average gaps in certain subjects in the eight Latin American and Caribbean countries that participated in the 2012 Programme for International Student Assessment (PISA). ${ }^{8}$ In math, the average gap was 0.19 standard deviations, favoring boys (OECD OECD 2012). In reading, the average gap favored girls by 0.27 standard deviations (OECD 2012). ${ }^{9}$

Consider a crude estimation of the potential impact of the math gap on earnings in the region. Focus only on men and women who work for pay. Recall that in 2013, women received US\$87, while men received US\$100 for the same type of work (Economic Commission for Latin America and the Caribbean (ECLAC) 2015). Hanushek (2011) estimated that a one standard deviation above average can lead to an expected increase in earnings of up to $15 \%$. Closing the mathematics gender gap would imply that a woman would earn US\$87*[1+(0.19*0.15)] =US\$89 for every US\$100 a man makes, instead of US\$87. Closing the skill gap in math would thus reduce the earnings gap by $15 \%$ [(89-87)/13]. Closing the reading skill gap would increase the earnings gap.

Gender gaps in skills can result from differential treatment starting early in life (Qian 2008; Barcellos et al. 2014). The brain is malleable to experiences, especially in the first years of life (Wood et al. 2008; Teasdale and Owen 1984; Wilson 1983). Studies on twins show that even if about $50 \%$ of the variance in child development is due to genetic factors, a child's genetic expression is influenced by environmental inputs (Teasdale and Owen 1984; Wilson 1983). Bando et al. (2016) studied language and socio-emotional skills of young children and found that girls outperformed boys as early as seven months of age in Chile and Nicaragua. ${ }^{10}$ This suggests that the gaps in language observed on the PISA tests for 15-year-olds may start as early as infancy. The gender gap in language in PISA is present in all countries despite variation in culture and educational structures (World Bank 2012). However, these differences are small relative to the difference in performance across children from different socioeconomic status.

\subsubsection{Identity effects}

Later in life, gender norms can affect gender gaps via psychological effects. Akerloff and Kranton (Akerlof and Kranton 2002) noted that people adapt behavior to follow the ideals of the social category with which they identify. They called this phenomenon "identity effects." In other words, individuals adjust their behavior to comply with the norms of the group to which they perceive themselves as pertaining, regardless of skill. This behavior starts around the age of six (Wetherell 1996). For example, a woman who chooses an occupation to feel feminine or a man who chooses an occupation to feel masculine are displaying identity effects.

\footnotetext{
$\overline{8}$ The PISA, an OECD initiative to evaluate educational systems, measures what 15-year-old students can do with what they know.

9 The average gap was 0.07 and 0.40 standard deviations in math and reading, respectively, in countries outside the region (OECD 2012).

10 The author did not find evidence that household characteristics, parental care practices, or health were related to gender gaps in infants.
} 
Gender roles in Latin America and the Caribbean reflect the Catholic influence in the region. Indeed, the share of people of Catholic descent in Latin America and the Caribbean is larger than that of any other region in the world. In 2014, 84\% of adults in the region declared they had been raised as a Catholic (Pew Research Center 2014). In the Catholic religion, the ideal of femininity is modeled by the Virgin Mary, the mother of Jesus. Marianismo considers women to be nurturing and morally superior to men, and holds that women should be willing to engage in self-sacrifice to benefit society, especially the family. Thus, social norms declare women to be better suited to meet family needs, with special emphasis on the education and rearing of children (Bachrach 1991; Cianelli et al. 2008). On the other hand, social norms in Latin America and the Caribbean define men to be better suited to defend their self-image as strong and dominant leaders. Machismo places expectations on men to take on high-risk behaviors, be aggressive, and show immunity to emotional pain (Lavrin 1987; Cianelli et al. 2008). These gender norms are likely to impose differential social benefits and costs to promote a fit between sex and gender when an individual chooses an occupation (World Bank 2012; ILO 2016).

\subsection{Social preferences}

Gender norms can affect occupational choice via demand reflecting social preferences. The psychology literature has proposed gender stereotypes affect the way people behave and treat others (Ellemers 2018). Indeed, suppose many people were willing to pay a higher price for a good or service when provided by a person of a specific sex. This phenomenon is clear in performance of some forms of arts and sports. If supply is not different between the two groups, then preferences will lead to different wages via demand. There is no evidence on how stereotypes influence wages. However, there is evidence that show stereotypes may influence demand. Ganguli, Hausmann, and Viarengo (2010) analyzed marriage and skill patterns in Latin America and concluded that men assign a high value to having a stay-at-home wife. They found that skilled women are less likely to marry than unskilled ones. Another piece of evidence is provided by Nopo (2012) found that newspapers and commercial magazines in Colombia display individuals in occupations to match gender stereotypes and are tailored to social preferences to maximize sales. In this way, gender norms influence social preferences, which in turn influence demand. Demand for specific attributes in terms of the sex of a person who provides a good or service influences the employment gender gap.

Becker (1971) proposed "taste discrimination" as a cause for gender gaps. Taste discrimination refers to the willingness of society to pay a lower price when a good is made or a service is provided by a person of a minority group. According to Becker's theory, discrimination derives from an individual distaste for either women or men. There is no evidence on how individual taste for labor provided by persons of a specific sex affects employment.

\subsection{The role of technology}

Technology influences how social norms and biology influence labor outcomes. Economists have long postulated this idea. Hicks (1932) and Roy (1951) explored the role of technology in the relationship between individual skills and occupational choice. There is evidence of a positive association between technology and gender equality. Cubas 
(2016) found that the price of household appliances and access to infrastructure explains cross-country female employment in Latin America. Another technological advance that influences gender gaps is family planning. Bailey, Hershbein, and Miller (2012) estimated that access to the birth control pill in the 1960s and 1970s allowed young women to earn an $8 \%$ higher hourly wage premium by age 50 in the USA. ${ }^{11}$

\subsection{The role of institutions}

Economics has long acknowledged the role of institutions. For example, Coase (1960) highlighted the importance of legal rules to regulate labor. Institutions are especially important to protect individual, property, and labor rights.

\subsubsection{Institutions and human rights}

Most countries in Latin America and the Caribbean have laws in place to prevent people employed or looking for employment from being discriminated against based on sex (Pagés and Piras 2010). Moreover, most countries have maternity protection, laws on day care services, and laws on leave to take care of sick children (Pagés and Piras 2010). However, only 8 out of 29 countries in Latin America and the Caribbean had laws in place to mandate equal remuneration across genders in 2015 (World Bank 2016).

A challenge in the region is that institutions may have limited reach to enforce laws. Indeed, about half of those employed in Latin America and the Caribbean work in the informal sector (ILO 2015b) and are not covered by the legal framework. ${ }^{12}$ Women are overrepresented in the informal sector in Latin America and the Caribbean, except in Bolivia and Venezuela (ILO 2013b).

\subsubsection{Statistical discrimination}

Arrow (1973) suggested that discrimination could be a product of information problems. The idea behind statistical discrimination is that employers build beliefs on productivity based on statistics. For example, if employers assume that individuals perform at the same level as their group average, they will be discriminating against those who perform above the average. A woman who applies for a job in a non-traditional female occupation where a few other women have performed poorly may be assumed to be less fit for it. Moreover, if productivity changes, then a lag in data generation will extend statistical discrimination in time. Testing for statistical discrimination is difficult. Standard approaches (such as standard audit studies) confound taste discrimination and statistical discrimination. Thus, there is no evidence on whether statistical discrimination does or does not exist in Latin America and the Caribbean.

The next section discusses evidence on policies implemented in the region to address employment gender gaps. These include policies associated with providing equal opportunities to all persons, relevant technology, and laws to promote gender equality.

\footnotetext{
11 The birth control pill was first approved for use in 1960 in the USA. World historians credit it as a key technology in transferring reproductive rights from men to women (Roberts 2013). Today, three forms of birth control are on the World Health Organization's list of important medications needed in a basic health system (WHO 2015).

12 The informal sector is broadly characterized as consisting of units engaged in the production of goods or services with the primary objective of generating employment and income for the persons concerned. These units typically operate at a low level of organization, with little or no division between labor and capital as factors of production and on a small scale. Labor relations-where they exist-are based mostly on casual employment, kinship, or personal and social relations rather than contractual arrangements with formal guarantees (ILO 1993).
} 


\section{Proposed solutions to gender gaps in pay}

There has been extensive work to identify effective policies to close the gender gap in pay. This section summarizes the empirical work in the last 10 years in the region. The available evidence supports the idea that women disproportionately assume the cost of raising a family. On the other hand, skill gaps or gender discrimination during the hiring process do not seem to play a major role. The implementation of laws results in changes in incentives for society, which affect gender gaps.

Table 2 summarizes the theoretical mechanisms proposed to explain the gender pay gap. The first column summarizes the theoretical causes discussed in the previous section. The second column summarizes interventions in Latin America and the Caribbean to address each theoretical factor. However, interventions can often address many theoretical causes of the gender gap. Thus, linking theory and evidence is not a straightforward exercise. The table associates theoretical causes with interventions that in principle aim to primarily address them. The table lists results on intermediate outcomes if there were no studies on labor outcomes. The evidence presented in the table is discussed in the sections that follow.

\subsection{Ensure that there are no differences in opportunities across gender groups}

Education is likely to play an important role in moderating biological predispositions (Cunha and Heckman 2009). Unfortunately, education is probably not yet addressing inequalities between women and men in Latin America and the Caribbean, other than access. For example, Bassi et al. (2016) found that teachers pay less attention to female students in class in Chile. Moreover, Nopo (2012) found that textbooks depict gender roles in Peru.

Biological predispositions may demand differential job accommodations. For example, consider the birth of a child. Goldin (2014) analyzed US wage patterns and hours of work demanded by occupations from 1970 to 2011 and found that occupations with better pay demanded continuous hours of work. Corporate, legal, and financial jobs particularly penalized job interruptions. Goldin concluded that gender pay gaps could be explained by career interruptions or flexible schedules. Indeed, childbearing tends to reduce the wage of mothers worldwide (Simonsen and Skipper 2012; ILO 2015c). In Latin America and the Caribbean, Piras and Ripani (2005) studied labor patterns in Bolivia, Brazil, Ecuador, and Peru and found that in 1999, mothers with children age 7 or younger were less likely to have a paid job compared to men or women without children.

For women who work, Gamboa and Zuluaga (2013) identified a "motherhood penalty" of $1.8 \%$ in Colombia. In other words, mothers were paid $1.8 \%$ less than women not having children. For their part, Atal et al. (2009) identified a "family penalty" for both men and women. However, women were more affected because more women tend to drop out of work to raise their families. ${ }^{13}$ Indeed, women said work-family balance is

\footnotetext{
${ }^{13}$ Consistent with social gender roles, the mother is usually the main caregiver of the child. For example, consider single-parent households in Brazil and Mexico. As many as $88 \%$ of these households were constituted by single mothers in 2010 (United Nations 2015b). The share of single-parent households overall in Brazil and Mexico was 11.1\% and 7.4\%, respectively (United Nations 2015b). In addition to single-parent families, the share of informal unions outside of marriage is increasing in the region. Indeed, around $48 \%$ of women between 25 and 29 years old lived in consensual union in the Dominican Republic and Panama in 2010 (United Nations 2015b). This share is above 30\% in Argentina, Colombia, Ecuador, Guyana, and Uruguay (United Nations 2015b)
} 
Table 2 Individual, societal, technological, and institutional factors that influence women's paid work. Source: Prepared by the author

\begin{tabular}{l} 
Factors \\
\hline a. Factors related to individual characteristics \\
1. Nature. Individual skills and preferences are influ- \\
enced by fixed biological predispositions such as \\
physical, neurological, and reproductive processes \\
(Welch 2000; Bertrand 2011; Jayachandran 2015)
\end{tabular}

2. Nurture. Individual skills result from human capita investment such as education and job experience (Mincer and Polachek 1974)

3. Identity effects. Individuals' preference to comply with their gender social ideals is determined by their identity (Akerlof and Kranton 2002)

$b$. Factors related to social preferences

4. Stereotypes or taste discrimination. Society pays a higher price when a good is made or a service is provided by a person of a specific sex (Becker 1971; Ellemers 2018)

c. Factors related to technology

5. Technology changes the relative productivity among gender groups (Hicks 1932; Albanesi and Olivetti 2015)

\section{d. Factors related to institutions}

6. Rights. Institutions protect labor or individual rights and provide social protection (Coase 1960; Blau and Kahn 1999)

7. Statistical discrimination. Employers do not have complete information on job applicants. Employers extrapolate productivity based on the sex of the individual (Arrow 1973)
Empirical evidence on the effectiveness of policies that promote women's paid work in Latin America and the Caribbean

Women may have a biological predisposition to assume a higher cost if children are not taken care of, and therefore may be more strongly motivated than men to take care of children. Childcare services have improved female labor participation in Argentina, Brazil, Colombia, and Ecuador (Attanasio and VeraHernandez 2004; Barros et al. 2011; Calderón 2012; Rosero and Oosterbeek 2011; Berlinski and Galiani 2007; Berlinski et al. 2011)

Training for work in Peru, Chile, Argentina, Colombia, and Peru have led to increases in female employment (Valdivia 2015; Kaplan et al. 2015; Aedo and Nuñez 2004; Ñopo et al. 2007).

Courses for the unemployed in the region have been successful in increasing female labor participation (Gonzalez-Velosa et al. 2012; Urzúa and Puentes 2010)

The author could not identify rigorous studies on the effects of policies that aim to change individual depictions of social roles

There are no studies on the direct effects of taste discrimination on employment. However, Ganguli et al. (2010) analyzed marriage and skill patterns in the region and found that skilled women in Latin America are less likely to marry than unskilled women. They conclude that men assign a high value to having a stay-at-home wife, while women do not

There is no evidence of the effect of technology on female employment. However, Cubas (2016) found that the price of household appliances and access to infrastructure explains cross-country female employment in Latin America

The implementation of laws for firms to provide maternity leave and unemployment severance in Colombia has resulted in lower employment of female labor (Molinos 2012; Ramirez et al. 2015; Pagés and Piras 2010)

Laws that allow firms to hire part-time employees and that promote flexible work schedules in Argentina have promoted female employment (Bosch and Maloney 2010; Pagés and Piras 2010)

There are no studies on the effects of policies that aim to address specific types of discrimination. However, Arceo-Gomez and Campos-Vázquez (2014b) found that women have a higher probability of receiving a callback than men after submitting a résumé to apply for employment in Mexico. Married women were less likely to receive a callback than single women. Moreno et al. (2012) found limited evidence of gender discrimination by intermediary employment services in Peru 
the main obstacle to professional development (Thompson Reuters Foundation 2015). A survey by the ILO in 2015 covering more than 1300 private companies in 39 developing countries ranked family responsibilities as the main barrier to women's leadership (ILO 2015a).

Policies to reduce the cost of motherhood have led to reductions in the gender pay gap. Childcare services and flexible work schedules have increased female employment in Latin America and the Caribbean (Attanasio and Vera-Hernandez 2004; Barros et al. 2011; Rosero and Oosterbeek 2011; Berlinski and Galiani 2007; Berlinski et al. 2011; Goldin 2014).

\subsection{Use technology to reduce gender gaps}

Technology has probably played the most important role in the shift in the gender gap in the last 25 years in Latin America and the Caribbean. Consider the use of contraception to regulate fertility. The average prevalence of using modern contraception among women ages 15 to 49 was $53 \%$ for 12 countries in Latin America and the Caribbean in 2006, ranging from 67\% in Mexico to only 25\% in Haiti (World Bank 2016). ${ }^{14}$ Miller (2010) found evidence for Colombia that family planning programs reduced fertility. ${ }^{15}$ Figure 2 shows that fertility decreased at a faster rate in the region in the 14 years from 1991 to 2014 than in the rest of the world. The increase in female labor participation in Latin America and the Caribbean in the last 25 years was accompanied by a decrease in fertility. Cruces and Galiani (2007) found that having one more child decreases the probability of the mother working for pay or profit in Argentina and Mexico. ${ }^{16}$

Evidence in the USA and the UK suggests that other technologies, including maternal health, infant formula, and home appliance ownership, have increased the participation of women in the labor market (Albanesi and Olivetti 2015; Cohen-Pirani et al. 2010; Cavalcanti and Tavares 2008). New technologies may be enabling different schemes for work participation. For example, Internet access is allowing greater flexibility in work schedules and facilitating work from home. It remains a question how technology affects hours of work and whether it affects pay for women and men.

\footnotetext{
${ }^{14}$ In general, the average fertility rate decreased in Latin America and the Caribbean from 3.16 to 2.12 children per family between 1991 and 2014 (World Bank 2016).

15 The 12 countries were Belize, Brazil, Chile, Cuba, Dominican Republic, Honduras, Haiti, St. Kitts and Nevis, Mexico, Peru, Trinidad and Tobago, and St. Vincent and the Grenadines.

16 Technology alone is far from enough to offset gender gaps. For example, the teen pregnancy rate in Latin America and the Caribbean is the second highest across regions in the world, despite the availability of contraception. The rate was 79 births per 1000 15-19-year-old women in 2010 (ECLAC 2013). Teenage pregnancy limits educational achievement and causes poverty (Arceo-Gomez and Campos-Vázquez 2014a; Hoffman and Maynard 2008). Despite this, a study in 2010 found that only 4 out of 10 teenagers in a relationship who do not wish to get pregnant use birth control (Guttmacher Institute 2010). The lack of use was not an information problem because 9 out of 10 teenagers knew about contraceptive methods (Guttmacher Institute 2010). La Ferrara et al. (2012) found that soap operas in Brazil showing the benefits of lower fertility led to smaller families in areas with low socioeconomic status. For a discussion on fertility see Guianne (2011).
} 


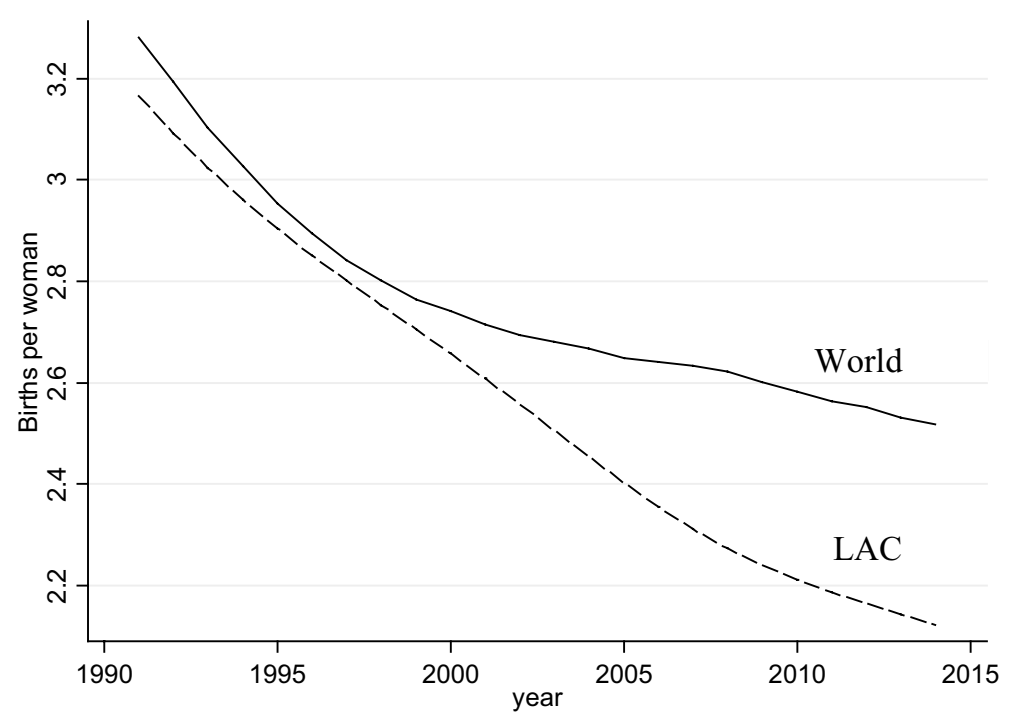

Fig. 2 Average fertility rate in Latin America and the Caribbean versus the rest of the world, 1991-2014. Source: Author's calculations based on data from World Bank (2016). LAC Latin America and the Caribbean

\subsection{Strengthen institutions to ensure human, labor, and property rights}

This section summarizes the importance of institutions to avoid discrimination, provide social protection, allow for the exercise of human rights, and enhance democratic participation and good government in Latin America and the Caribbean.

\subsubsection{Government intervention is key to prevent discrimination}

Regulation is important when differences in skills may lead to gender statistical discrimination. Consider official learning validation and certification. UNESCO and UNHCR (2016) find that these are often ignored in the provision of quality education. There are scant standardized tests that enable employers to determine which applicants for a position have the skills they need. The completion rate for secondary education is $41.6 \%$ in Latin America and the Caribbean (UNESCO 2016a, b). However, it is still an open question whether employers' perceptions of skills result in discrimination.

\subsubsection{Government intervention is key to ensure social protection}

Social protection is linked to formal work. For example, pension contribution rates in Chile are 96\% among men but only 75\% among women, while in El Salvador pension contribution rates are $85 \%$ among men but only $55 \%$ among women (Bosch et al. 2013). In the Latin America and the Caribbean region, the gap closes at the time pensions are received, when $65 \%$ of men and $61 \%$ of women 65 years or older receive a pension (Bosch et al. 2013). Therefore, women are more likely to demand social assistance rather than to become entitled to pensions. Thus, policies to reduce informality are likely to disproportionately benefit women.

\subsubsection{Government intervention is necessary to ensure human rights}

Latin America and the Caribbean has the dubious distinction of being the most violent region in the world. The homicide rate was 29.3 among men and 3.7 among women per 
100,000 population in 2012 (UNODC 2013). While violence disproportionately affects men, the shape of that violence is different across the sexes. Most women are killed by people expected to care for them, while men are killed by people they may not know (UNODC 2013). Half of female homicide victims are killed by an intimate partner; in contrast, $6 \%$ of male homicide victims are killed by an intimate partner (UNODC 2013). Many countries have adapted their regulatory framework to address human rights across sex groups. For example, 18 of 29 countries in Latin America and the Caribbean have explicitly criminalized marital rape (World Bank 2016). However, there is still work to be done in the rest of the countries. In addition, enforcement of the law may not be ideal. Ensuring individual rights for women may be costlier than ensuring those rights for men, given that ensuring rights for women requires regulation within the household. More research is needed in this area.

\subsubsection{Government intervention is necessary to enhance good government}

The democratic process demands inclusive citizen participation. However, gender gaps in occupations extend to participation in the political process. Consider the participation of women in political positions at the national level. By 2015, all Latin American countries except Guatemala and Venezuela had laws to promote female participation (Freidenberg and Lajas 2015). In 2015, women occupied 27\% of national parliamentary seats in the region (ECLAC 2015), far short of their share of the population.

One frequent approach to promoting female political participation is to set gender quotas. Zetterberg (2009) finds that gender quotas have a limited impact on political trust, knowledge, or interest among women. He concludes that women do not perceive quotas as empowering in Latin America, and he argues that informal nomination procedures favor women with close ties to particular leaders. Thus, the process sends the message that procedures are unfair and that they discourage qualified women. ${ }^{17}$

Table 3 summarizes the goals and evidence of related gaps discussed in this section and lists related articles in the Declaration of Human Rights. The solution to the gender gap is a combination of policies to enhance equality of opportunities, guarantee equal access to salaried positions, promote the use of technology, and strengthen institutions. Taken together, these policies are directed to enhancing the exercise of human rights.

To sum up, formal institutions are important to ensure that citizens can exercise their human rights and be free of discrimination. Formal institutions play a central role in facilitating coordinated and collective action and providing social protection. Participation in the democratic process provides incentives for shaping and maintaining good government. The main challenge is to enforce regulations for individuals trading within the household or in informal markets. Another challenge is how to promote participation by women in the democratic process. Policies to address these issues are likely to promote gender equality. Addressing these issues would benefit not only to women but also men in similar circumstances. The next section discusses why identifying more specific policies may be challenging.

\footnotetext{
${ }^{17}$ Corporate quotas in the region have not been evaluated. However, evidence from Norway shows that the participation of women on boards led to changes in management practices that reduced short-term profits (Pande and Ford 2014). Cross-country comparisons show that political and corporate entities tend to avoid the intended impact of quotas (Pande and Ford 2014).
} 


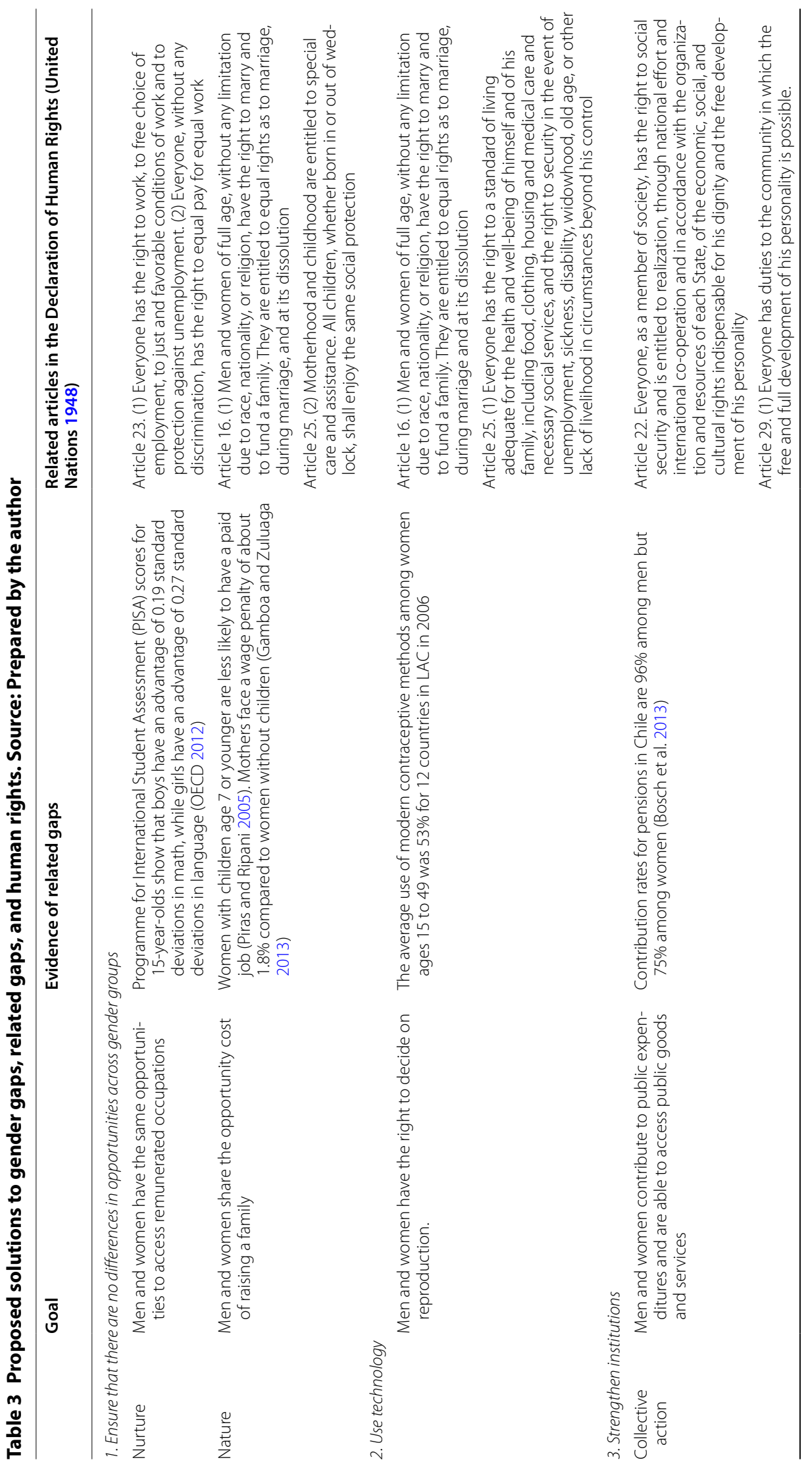




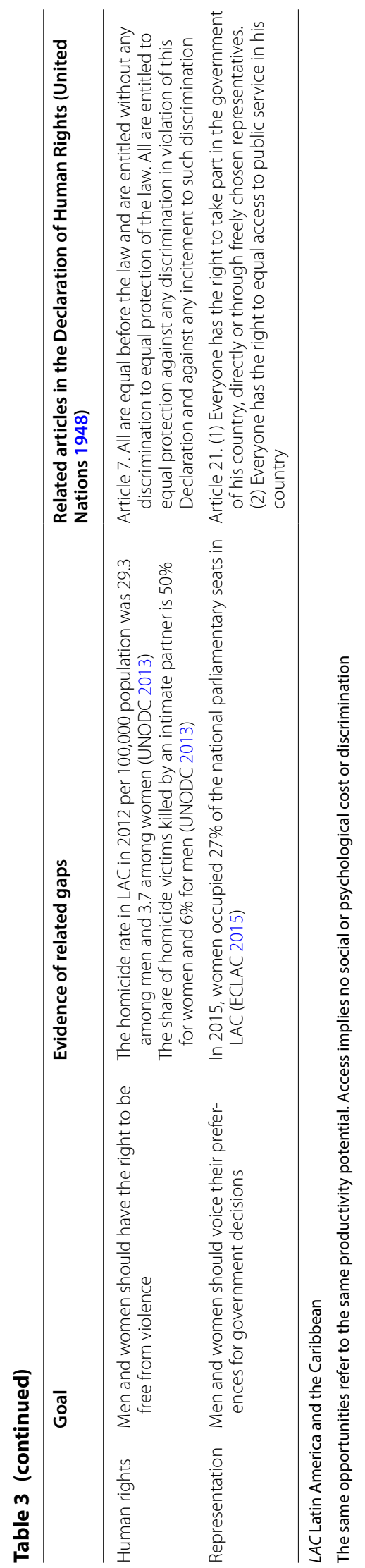




\section{Challenges to identifying evidence-based gender equality policies}

Promoting gender equality based on evidence is not easy. There are important areas where better evidence is needed to design policy. This section lists the main challenges to identifying evidence-based policies to promote gender equality.

The first policy challenge is to better understand individual choices on occupations. There is a need to understand the role of nature versus nurture in this choice, as well as the mechanisms through which society influences these choices. The second challenge is to better understand how to use technology responsibly. Indeed, technology may bring controversial results, such as facilitating abortion or increasing the double burden on individuals (i.e., the workload of people who have jobs and are also responsible for unpaid domestic labor). There is a need to better understand the effects of programs that provide family planning, as well as technological advances such as Internet access that facilitate working from home. The third challenge is to better understand how to strengthen institutions and make them more inclusive while respecting privacy. Indeed, transactions within the household limit the ability of the government to act.

A better understanding of individual choices, the use of technology, and the reach of institutions would aid international efforts to identify effective evidence-based policy. However, research related to gender gaps faces many challenges. The first is to identify specific mechanisms relevant for policymaking. For example, consider vouchers to subsidize wages. Vouchers have resulted in a higher probability of employment among women in Argentina (Galasso et al. 2004). However, it is difficult to determine a longterm solution using vouchers. The subsidy could address several contributing factors to gender inequality, including shortcomings in productivity, compensation for discrimination, or higher regulatory costs. But it is difficult to tell if such subsidies contribute to close the gender gap over the long term or are just a temporary fix.

Two mechanisms especially difficult to separate are those related to individual and social behavior. Individuals adapt their behavior according to what others do. For example, married men in the Philippines changed their expenditure choices when their wives knew they received money (Ashraf 2009). Gender interventions are prone to triggering broad social effects. In these cases, the researcher will not be able to separate the group effect from the sum of aggregated individual effects. This problem is known as the reflection problem, and it was first proposed by Manski (2000).

A second challenge is the difficulty of obtaining relevant data. For example, current public data do not allow for ascertaining how much of the increase in women's labor is a substitution for unpaid work. Many organizations are currently working to collect these data through time-use and employment surveys. For example, the Organization for Economic Co-operation and Development (OECD), United Nations, and World Bank are starting to put together data collected across countries. ${ }^{18}$

\footnotetext{
18 Other examples of data limitation are the lack of information on time allocation by gender for the region. There is not enough information to explore how occupational segregation conditional on paid work has changed in the region, or how pay gender gaps conditional on a given occupation have evolved. For OECD data collection efforts, see https:// www.oecd.org/gender/data/ (Chile and Mexico). For the United Nations, see http://unstats.un.org/unsd/gender/defau lt.html. For the World Bank, see http://data.worldbank.org/topic/gender. For a description on the number of countries with data available, see http://unstats.un.org/unsd/gender/dataWW2015.html. All sites accessed on December 21, 2016.
} 
Another data-related challenge is that men and women differ in dimensions other than sex, including developmental history. ${ }^{19}$ In addition, gender gaps are related, in part, to behavior that takes place within the household and to labor not traded in the labor market. In addition, observers may induce unconscious bias in research. Thus, measurement may be costly and prone to bias.

The third challenge is that factors that influence the gender gap may not be detected with a single statistic. Consider the distribution of skills across the sexes. Assume that both men and women have a standard normal distribution with a common mean. However, suppose the variance is different among groups. Heckman (1998) notes this case will result in different shares across a common threshold value other than the mean. Thus, using a common rule for both groups may result in gaps. ${ }^{20}$

Despite these limitations, there are opportunities to generate evidence. Various policies already in place lack a formal evaluation. For instance, gender firm certification programs aim to ensure equal treatment across genders in several dimensions, including recruiting, professional development, pay, work-life balance, and sexual harassment. Programs currently operate in Argentina, Brazil, Chile, Costa Rica, Mexico, and Uruguay (Inter-American Development Bank 2015), yet they have not been evaluated. Programs with the goal of changing social norms also need more evaluation. For example, the Somos Diferentes, Somos Iguales Program in Nicaragua, and Program H and Program $\mathrm{M}$ in El Salvador and Brazil are only recently being evaluated (Inter-American Development Bank 2015; Promundo 2016; United Nations 2011; Bando et al. 2019). Programs that provide multiple services in a single geographical point also need to be studied. For instance, Ciudad Mujer in El Salvador provides labor intermediation, health, psychology, legal, and childcare services. Researchers are currently studying this program (InterAmerican Development Bank 2015).

Another opportunity to generate evidence is to consider gender in broader development research. Evaluating sex-specific delivery of goods and services should aid learning and improve understanding of how to promote inclusive development. Better data and a better understanding of those data promote innovation. For example, in Latin America electricity is more expensive for residential use than commercial use. Women are more likely to own a small home business. Thus, considering other inputs for production as equal, women face a higher price for production (Komives et al. 2005). This finding indicates that a flat rate for electricity affects opportunities for one group more than the other.

Including gender in policies to promote development may also prevent unexpected adverse effects. Policies that ignore gender could result in unequal access, violate human rights, or increase violence. However, flexible works schedules may result in women working more hours to meet expectations. Another example is that of conditional

\footnotetext{
${ }^{19}$ Researchers are likely to face challenges in finding comparable individuals to construct a proper sample. In an extreme, the researcher may not be able to observe one sex at all. Indeed, sorting of men and women into occupational tracks starts early in life. Research focusing on long periods of time may ameliorate this challenge and improve understanding of the dynamics of gender gaps.

${ }^{20}$ For example, suppose that both groups have the same average math scores, but men have more variation. Suppose that the passing score is above the mean. In this case, more men will pass the test. Thus, a researcher comparing the percentage that passes the test across the sexes will find a sex gap. Without knowing the threshold and the distribution, a researcher cannot tell if there was any discrimination. Therefore, researchers must remember that distributional differences may influence results. As a result, deriving lessons learned across studies becomes increasingly challenging.
} 
cash transfers in Mexico, where transfers to women resulted in short-term increases in domestic violence (Bobonis et al. 2013).

In summary, there are important areas to explore: the acquisition of skills and occupational choice, the use of technology, and the strengthening of institutions. Future work to identify policies to close gender gaps based on evidence will face challenges. First, research must pay attention to the many mechanisms through which an intervention affects gender gaps. Second, men and women differ in dimensions other than sex. Third, men and women may differ in statistics other than the mean. Despite these challenges, research in development could inform knowledge on how to address gender gaps and help avoid potential adverse gender effects.

\section{Conclusion}

The percentage of women employed has increased faster in Latin America and the Caribbean than in any other region in the world in the last 25 years. However, many women do not see the benefits of their work. Women work more hours than men, but half of women in Latin America and the Caribbean do not get pay or profit. The high share of women without pay leaves them with limited entitlement to benefits. Most women work at home or in the informal sector. Thus, they are less likely to benefit from legal protection. On average, women face more obstacles to benefiting from certain human and labor rights and rights as citizens.

Gender gaps result from biological predispositions and expectations by society as to what occupation persons of a given sex should choose and how much they should be paid. In Latin America and the Caribbean, gender roles have it that women are better suited than men to pursue activities that directly benefit the household or the family. Gender roles influence occupational choice and skills. Other factors such as discrimination, regulations, and technology also influence this choice.

Policies to reduce gender gaps can be grouped into three categories: policies that aim to ensure equality of opportunity across genders; policies directed toward the use technology; and policies to ensure individual rights.

Policy design and determining whether policies should be tailored across sexes demands clear answers to some outstanding questions. There is a need to understand the dynamics and long-term effects of human capital accumulation across sexes and how it affects individual choices. Thus, studies over long periods of time would be insightful. There is a need to learn how to protect labor and human rights within the household and in informal markets; to find ways to make social services more inclusive; to find ways to promote participation by all in the democratic process; and to understand how social norms modulate the use of technology to reduce gender gaps. In summary, given that men and women are not the same, there is a need to understand how both can enjoy equal opportunities and equal rights, and to find ways to spread the cost of unpaid labor more equally.

Research in this area faces several challenges. First, policies affect behavior through several pathways, so one needs to understand the roles of those pathways and how they interact in order to design effective policies. Second, researchers may face challenges in finding men and women with similar characteristics to construct a proper sample. Indeed, men and women are raised differently. Thus, long-term research may be 
necessary to understand a specific intervention net of current differences. Third, gender differences are likely to matter for policy design in distributional features other than the mean. Thus, detailed analysis is necessary to inform policy.

Interventions for development can further understanding about gender even when gender is not the central issue. Indeed, many current development studies provide key information about gender gaps. Consider studies on pensions, informality, and democratic participation. These development issues relate to the gender gap, so they represent an opportunity to generate evidence. Therefore, when possible, such development studies should include a careful gender analysis. These exercises would likely bring Latin America and the Caribbean closer to finding the answer to when and how to address gender gaps.

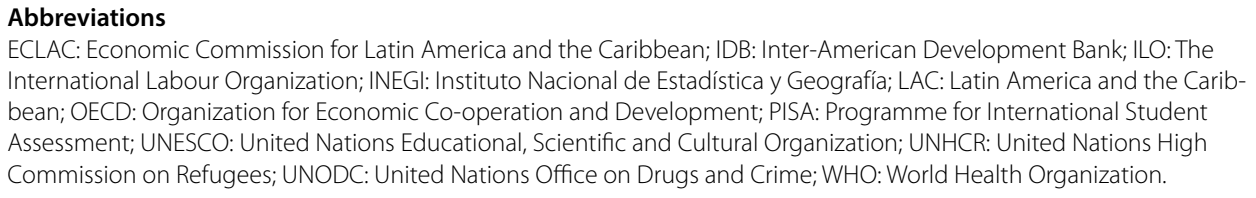
bean; OECD: Organization for Economic Co-operation and Development; PISA: Programme for International Student Assessment; UNESCO: United Nations Educational, Scientific and Cultural Organization; UNHCR: United Nations High Commission on Refugees; UNODC: United Nations Office on Drugs and Crime; WHO: World Health Organization.

\section{Acknowledgements}

I am grateful for valuable comments from members of the Strategic and Development Effectiveness Seminar at the Inter-American Development Bank and three anonymous referees. The views expressed here are my own. The opinions expressed in this publication are those of the author and do not necessarily reflect the views of the Inter-American Development Bank, its Board of Directors, or the countries they represent.

\section{Authors' contributions}

$\mathrm{RB}$ is responsible for the writing of this paper. The author read and approved the final manuscript.

\section{Authors' information}

This article was prepared for a special issue. The issue aims to provide a description of key development problems in the Latin America and the Caribbean Region. It also aims to identify the main restrictions to identify evidence-based policies.

Funding

Funding for the preparation of this paper was provided by the Inter-American Development Bank.

Availability of data and materials

All data used in this paper are public and available online.

Ethics approval and consent to participate

Not applicable.

\section{Consent for publication}

Not applicable.

Competing interests

The author declares no competing interests.

Received: 20 August 2019 Accepted: 21 October 2019

Published online: 31 October 2019

\section{References}

Aedo C, Nuñez S (2004) The impact of training policies in Latin America and the Caribbean: The case of Programa Joven. IDB Working Paper 483. Inter-American Development Bank, Washington, DC

Akerlof GA, Kranton RE (2002) Identity and schooling: some lessons for the economics of education. J Econ Lit 40(4):1167-1201

Albanesi S, Olivetti C (2015) Gender roles and medical progress. Staff Report No. 720. Federal Reserve Bank of New York Angelucci M, Karlan D, Zinman J (2015) Microcredit impacts: evidence from a randomized microcredit program placement experiment by Compartamos Banco. Am Econ J 7(1):151-182

Arceo-Gomez EO, Campos-Vázquez RM (2014a) Teenage pregnancy in Mexico: evolution and consequences. Latin Am J Econ 51(1):109-145

Arceo-Gomez EO, Campos-Vázquez RM (2014b) Race and marriage in the labor market: a discrimination correspondence study in a developing country. Am Econ Rev 104(5):376-380

Arrow KJ (1973) The theory of discrimination. In: Ashenfelter O, Rees A (eds) Discrimination in labor markets. Princeton University Press, Princeton 
Ashraf N (2009) Spousal control and intra-household decision making: an experimental study in the Philippines. Am Econ Rev 99(4):1245-1277

Atal JP, Ñopo H, Winder N (2009) New century, old disparities: Gender and ethnic wage gaps in Latin America. IDB Working Paper No. 109. Inter-American Development Bank, Washington, DC

Attanasio O, Vera-Hernandez M (2004) Medium and long-run effects of nutrition of child care: Evaluation of a community nursery programme in rural Colombia. Paper No. EWP04/06. Center for the Evaluation of Development Policies, the Institute for Fiscal Studies

Bachrach ET (1991) Debunking marianismo: economic vulnerability and survival strategies among Guatemalan wives. Ethnology 30(1):1-16

Bailey MJ, Hershbein B, Miller AR (2012) The opt-in revolution? Contraception and the gender gap in wages. Am Econ J 4(3):225-254

Bando R, López-Bóo F, Li X (2016) Sex-differences in language and socio-emotional skills in early childhood. IDB Working Paper No. 714. Inter-American Development Bank, Washington, DC

Bando R, Hidalgo N, Land A (2019) Education with a social focus on gender attitudes: experimental evidence from secondary education in el salvador. J Econ Race Policy 19:1-5

Banerjee A, Karlan D, Zinman J (2015) Six randomized evaluations of microcredit: introduction and further steps. Am Econ $J 7(1): 1-21$

Barcellos SH, Carvalho LS, Lleras-Muney A (2014) Child gender and parental investments in India: are boys and girls treated differently? Am Econ J 6(1):157-189

Baron-Cohen S (2003) The essential difference: men, women, and the extreme male brain. Allan Lane, London

Barros R, Olinto P, Lunde T, Carvalho M (2011) The impact of access to free childcare on women's labor market outcomes: Evidence form a randomized trial in low-income neighborhoods of Rio de Janeiro. World Bank, Washington, DC. Unpublished. http://siteresources.worldbank.org/DEC/Resources/84797-1104597464088/59841 3-1302096012728/Pedro-Olinto_access_to_free_childcare.pdf

Bassi M, Blumber RL, Mateo DM (2016) Under the cloak of invisibility: Gender bias in teaching practices and learning outcomes. IDB Working Paper No. 696. Inter-American Development Bank, Washington, DC

Becker G (1965) A theory of the allocation of time. Econ J 75:493-517

Becker G (1971) The economics of discrimination. The University of Chicago Press, Chicago

Berlinski S, Galiani S (2007) The effect of a large expansion of pre-primary school facilities on preschool attendance and maternal employment. Lab Econ 14(3):665-680

Berlinski S, Galiani S, McEwan P (2011) Preschool and maternal labor market outcomes: evidence from a regression discontinuity design. Econ Dev Cult Change 59(2):313-344

Bertrand M (2011) New perspectives on gender. In: Ashtenfelter O, Card D (eds) Handbook of labor economics, vol 4b. North Holland, Amsterdam

Blau FD, Kahn LM (1999) Institutions and laws in the labor market. In: Ashtenfelter O, Card D (eds) Handbook of labor economics, vol 3. Elsevier, New York

Bobonis GJ, González-Brenes M, Castro R (2013) Public transfers and domestic violence: the roles of private information and spousal control. Am Econ J 5(1):179-205

Bosch M, Maloney WF (2010) Comparative analysis of labor market dynamics using Markov processes: an application to informality. Lab Econ 17(4):621-631

Bosch M, Melguizo A, Pagés C (2013) Better pensions better jobs: towards universal coverage in Latin America and the Caribbean. Inter-American Development Bank, Washington, DC

Buser Thomas (2012) Digit ratios, the menstrual cycle and social preferences. Games Econ Behav 76(2):457-470

Calderón G (2012) What is good for the goose is good for the gander: child care, female labor force participation and men mobility to better jobs in Mexico, Stanford University, manuscript

Campos-Vázquez RM, Hincapié A, Rojas-Valdés RI (2012) Family income inequality and the role of married women earnings in Mexico: 1998-2010. Latin Am J Econ 49(1):67-98

Cavalcanti TV, Tavares J (2008) Assessing the "engines of liberation": home appliances and female labor force participation. Rev Econ Stat 90(1):80-88

Cianelli R, Ferrer L, McElmurry BJ (2008) HIV prevention and low-income Chilean women: machismo, marianismo, and HIV misconceptions. Cult Health Sex 10:297-306

Coase R (1960) The problem of social cost. J Law Econ 3:1-44

Cohen-Pirani D, Leon A, Lugauer S (2010) The effect of household appliances on female labor participation: evidence form micro data. Labour Econ 17(3):503-513

Cruces G, Galiani S (2007) Fertility and male labor supply in Latin America: new causal evidence. Labour Econ 14:565-573

Cubas German (2016) Distortions, infrastructure, and female labor supply in developing countries. Eur Econ Rev 87(August):194-215

Cunha F, Heckman JJ (2009) The economics and psychology of inequality and human development. J Eur Econ Assoc 7(2-3):320-364

De Pisapia N, Bornstein MH, Rigo P, Esposito G, De Falco S, Venuti P (2013) Gender differences in directional brain responses to infant hunger cries. NeuroReport 24(3):1421-1426

Dreber A, Hoffman M (2007) Portfolio selection in utero. Working paper. University of Chicago

Duflo E (2003) Grandmothers and granddaughters: old-age pensions and intrahousehold allocation in South Africa. World Bank Econ Rev 17(1):1-25

Duflo E (2012) Women empowerment and economic development. J Econ Lit 50(4):1051-1079

Duflo E, Udry C (2004) Intra-household resource allocation in Côte d'Ivoire: Social norms, separate accounts and consumption choices. NBER Working Paper No. 10498. National Bureau of Economic Research, Cambridge, MA

Economic Commission for Latin America and the Caribbean (ECLAC) (2013) CEPALSTAT bases de datos y publicaciones estadísticas: Infográficos de América Latina y el Caribe. ECLAC Statistics Division, Santiago. http://estadisticas.cepal .org/cepalstat/web_cepalstat/Library/CEPALSTAT/Infograficos_pdf/2013/Mortalidad_Materna_CEPAL_2013.pdf 
Economic Commission for Latin America and the Caribbean (ECLAC) (2015) América Latina y el Caribe: una mirada hacia el futuro desde los Objetivos de Desarrollo del Milenio. Informe regional de monitoreo de los Objetivos de Desarrollo del Milenio en América Latina y el Caribe, 2015. ECLAC. Santiago

Ellemers Naomi (2018) Gender stereotypes. Annu Rev Psychol 69(1):275-298

Freidenberg F, Lajas S (2015) Leyes de cuotas en América Latina para cargos de elección y sus reformas (1978-2015), Proyecto de reformas políticas en América Latina (1978-2015). Secretariat for Political Affairs, Organization of American States, Washington, DC

Galasso E, Ravallion M, Salvia A (2004) Assisting the transition from workfare to work: a randomized experiment. Ind Labor Relat Rev 58(1):128-142

Gamboa LF, Zuluaga B (2013) Is there a motherhood penalty? Decomposing the family wage gap in Colombia. J Fam Econ Issues 34(4):412-434

Ganguli I, Hausmann R, Viarengo M (2010) Schooling can't buy me love: Marriage, work, and the gender education gap in Latin America. CID Working Paper No. 197 (June). Center for International Development, Harvard University

Goldin C (2014) A grand gender convergence: its last chapter. American Economic Review 104(4):1091-1119

Gonzalez-Velosa C, Ripani L, Rosas-Schady N (2012) How can job opportunities for young people in Latin America be improved? IDB Technical Note No. TN-345. Inter-American Development Bank, Washington, DC

Guianne TW (2011) The historical fertility transition: a guide for economists. J Econ Lit 49(3):589-614

Guttmacher Institute (2010) Facts on the sexual and reproductive health of adolescent women in the developing world. In Brief. Guttmacher Institute and International Federation for Family Planning, New York

Hanushek AE (2011) Valuing teachers: how much is a good teacher worth? Educ Next 11(3):40-45

Heckman JJ (1998) Detecting discrimination. Journal of Economic Perspectives 12(2):101-116

Hicks JR (1932) The theory of wages. Macmillan, London

Hoffman SD, Maynard RA (eds) (2008) Kids having kids: economic costs and social consequences of teen pregnancy, 2nd edn. Urban Institute Press, Washington, DC

Instituto Nacional de Estadística y Geografía (INEGI) (2015) INEGI e Inmujeres presentan resultados de la encuesta nacional sobre uso de tiempo. Press Bulletin No. 273/15 (July). INEGI, Mexico. http://www.inegi.org.mx/saladepren sa/boletines/2015/especiales/especiales2015_07_2.pdf

Inter-American Development Bank (2015) La importancia del género y la diversidad en las estrategias de desarrollo en América Latina y el Caribe. Gender and Diversity Division, Inter-American Development Bank, Washington, DC

International Labour Organization (ILO) (1993) Resolutions concerning statistics of employment in the informal sector adopted by the 15th International Conference of Labour Statisticians (Paragraph 5). January. ILO, Geneva

International Labour Organization (ILO) (2013a) Resolution concerning statistics of work, employment and labour underutilization adopted by the Nineteenth International Conference of Labour Statisticians. ICLS-Resolution-I[STATI-131114-1]-En.docx. ILO, Geneva

International Labour Organization (ILO) (2013b) Women and men in the informal economy: a statistical picture, 2nd edn. ILO, Geneva

International Labour Organization (ILO) (2015a) Women in business and management: gaining momentum. Global Report, ILO, Geneva

International Labour Organization (ILO) (2015b) Panorama laboral 2015. América Latina y el Caribe. ILO Regional Office for Latin American and the Caribbean, Lima

International Labour Organization (ILO) (2015c) The motherhood pay gap: A review of the issues, theory and international evidence. Conditions of Work and Employment Series No. 57. ILO, Geneva

International Labour Organization (ILO) (2016) Women at work: trends 2016. ILO, Geneva

Jayachandran S (2015) The roots of gender inequality in developing countries. Ann Rev Econ 7:63-88

Kaplan D S, Novella R, Graciana R, Vazquez C (2015) Training vouchers in labor market outcomes in Chile. IDB Working Paper No. 585. Inter-American Development Bank, Washington, DC

Komives K, Foster V, Halpern J, Wodon Q (2005) Water, electricity, and the poor: Who benefits from utility subsidies?. World Bank, Washington DC

La Ferrara E, Chong A, Duryea S (2012) Soap operas and fertility: evidence from Brazil. Am Econ J 4(4):1-31

Lavrin A (1987) Women, the family, and social change in Latin America. World Affairs 150(2):109-128

Levine A, Zagoory-Sharon O, Feldman R, Weller A (2007) Oxytocin during pregnancy and early postpartum: individual patterns and maternal-fetal attachment. Peptides 28(6):1162-1169

Manski CF (2000) Economic analysis of social interactions. J Econ Perspect 14(3):115-136

Marlin BJ, Mitre M, D'amour JA, Chao MJ, Froemke RC (2015) Oxytocin enables maternal behavior by balancing cortical inhibition. Nature 520:499-504

Miller G (2010) Contraception as development? New evidence from family planning in Colombia. Econ J 120(545):709-736

Mincer J, Polachek S (1974) Family investment in human capital: earnings of women. J Pol Econ 82:S76-S108

Molinos C (2012) La Ley de protección a la maternidad como incentivo de participación laboral femenina: el caso colombiano. Coyuntura Económica 42(1):93-116

Moreno M, Ñopo H, Saavedra J, Torero M (2012) Detecting gender and racial discrimination in hiring through intermediation services: the case of selected occupations in metropolitan Lima, Peru. World Dev 40(2):315-328

Ñopo H (2012) The paradox of girls' educational attainment. Americas Quarterly. http://www.americasquarterly.org/theparadox-of-girls-educational-attainment

Ñopo H, Robles M, Saavedra J (2007) Occupational training to reduce gender segregation: The impacts of ProJoven. IDB Research Department Working Paper 623. Inter-American Development Bank, Washington, DC

Noriuchi M, Kikuchi Y, Senoo A (2008) The functional neuroanatomy of maternal love: mother's response to infant's attachment behaviors. Biol Psychiat 63(4):415-423

Organization for Economic Co-operation and Development (OECD) (2012) Program for International Student Assessment (PISA). http://www.oecd.org/pisa/keyfindings/pisa-2012-results.htm 
Pagés C, Piras C (2010) The gender dividend: Capitalizing on women's work. Inter-American Development Bank, Washington, DC. https://publications.iadb.org/handle/11319/450

Pande R, Ford D (2014) Gender quotas and female leadership: A review. eSocialSciences Working Paper. http://EconP apers.repec.org/RePEc:ess:wpaper:id:5945

Pearson M, Burkhard CS (2013) Menstrual cycle and competitive bidding. Games Econ Behav 78(March):1-20

Pew Research Center (2014) Religion in Latin America: Widespread change in a historically Catholic region. November

Piras C, Ripani L (2005) The effects of motherhood on wages and labor force participation: Evidence from Bolivia, Brazil, Ecuador and Peru. Technical Paper WID-109. Sustainable Development Department, Inter-American Development Bank, Washington, DC

Promundo (2016) Program H. Washington, DC. http://promundoglobal.org/programs/program-h/

Qian N (2008) Missing women and the price of tea in China: the effect of sex-specific earnings on sex imbalance. Q J Econ 123(3):1251-1285

Ramirez BN, Tribin UAM, Vargas CO (2015) Maternity and labor markets: Impact of legislation in Colombia. IDB Working Paper No. 583. Inter-American Development Bank, Washington, DC

Ricardo D (1821) On the principles of political economy and taxation. Library of Economics and Liberty. http://www. econlib.org/library/Ricardo/ricP.html

Roberts JM (2013) The penguin history of the world, 6th edn. Penguin, New York

Rosero J, Oosterbeek H (2011) Trade-offs between different early childhood interventions: evidence from Ecuador. Tinbergen Institute Discussion Paper T1 2011-102/3

Roy AD (1951) Some thoughts on the distribution of earnings. Oxford Econ Paper 3(2):135-146

Simonsen M, Skipper L (2012) The family gap in wages: what wombmates reveal. Labour Econ 19:102-112

Teasdale TW, Owen DR (1984) Heredity and familial environment in intelligence and educational level—a sibling study. Nature 309(June):620-622

Thomas D (1990) Intra-household resource allocation: an inferential approach. J Hum Resour 25(4):635-664

Thompson Reuters Foundation (2015) The 5 key issues facing women working in the G20. Rockefeller Foundation. http:// www.poll2015.trust.org

Udry C (1996) Gender, agricultural production and the theory of the household. J Pol Econ 104(5):1010-1046

United Nations (1948) The Universal Declaration of Human Rights. General Assembly Resolution 217 A. Paris

United Nations (2011) Somos diferentes, somos iguales: Un entorno favorable para Centroamérica. Secretary-General of the United Nations. http://www.puntos.org.ni

United Nations (2015a) Progress of the world's women 2015-2016: Transforming economies, realizing rights. United Nations Women, New York

United Nations (2015b) The world's women 2015: Trends and statistics. Statistics Division, Department of Economic and Social Affairs, United Nations, New York. www.unstats.un.org/unsd/gender/worldwomen.html

United Nations Educational, Scientific and Cultural Organization (UNESCO) (2016a) Global education monitoring report: Gender review. Creating sustainable futures for all. UNESCO, Paris

United Nations Educational, Scientific and Cultural Organization (UNESCO), United Nations High Commission on Refugees (UNHCR) (2016b) No more excuses: Provide education for all forcibly displaced people. Global Education Monitoring Report Policy Paper 26. UNESCO, Paris

United Nations Office on Drugs and Crime (UNODC) (2013) Global study on homicide 2013: trends, contexts, data. UNODC, Vienna

Urzúa S, Puentes E (2010) La evidencia del impacto de los programas de capacitación en el desempeño en el mercado laboral. IDB Technical Note No. 268. Inter-American Development Bank, Washington, DC

Valdivia M (2015) Business training plus for female entrepreneurship? Short- and medium-term experimental evidence from Peru. J Dev Econ 113(C):33-51

Welch F (2000) Growth in women's relative wages and in inequality among men: one phenomenon or two? Am Econ Rev 90(2):444-449

Wetherell M (1996) Group conflict and the social psychology of racism. In: Wetherell M (ed) Identities, groups and social issues. Sage Publications, Thousand Oaks

Wilson RS (1983) The Louisville twin study: developmental synchronies in behavior. Child Dev 54(2):298-316

Wood JL, Heitmiller D, Andreasen DC, Nopoulos P (2008) Morphology of the ventral frontal cortex: relationship to femininity and social cognition. Cereb Cortex 18(3):534-540

World Bank (2012) World development report 2012: gender equality and development. World Bank, Washington DC

World Bank (2016) Database on gender statistics. World Bank, Washington DC. http://data.worldbank.org/data-catalog/ gender-statistics. Accessed 24 Oct 2016

World Health Organization (WHO) (2015) Model list of essential medicines: Adults. 19th edition. http://www.who.int/ medicines/publications/essentialmedicines/en/

Yañez-Pagans P (2014) Do we need more women in power? Gender, public policy, and development in Bolivia. IDB Working Paper No. 542. Inter-American Development Bank, Washington, DC

Zetterberg P (2009) Do gender quotas foster women's political engagement? Lessons from Latin America. Pol Res Q 62(4):715-730

\section{Publisher's Note}

Springer Nature remains neutral with regard to jurisdictional claims in published maps and institutional affiliations. 